\title{
Studi Literatur: Pengembangan Media Pembelajaran dengan Video Animasi Powtoon
}

\author{
${ }^{*}$ Titin', Ega Safitri ${ }^{2}$ \\ 1,2 Universitas Tanjungpura, Pontianak, Indonesia
}

\begin{tabular}{|c|c|}
\hline (A) Check for updates open access @) & DOI: https://doi.org/10.53621/jippmas.v1i2.12 \\
\hline Informasi Artikel & \multirow{4}{*}{$\begin{array}{l}\text { Penelitian ini bertujuan untuk mengetahui (1) kelayakan media } \\
\text { pembelajaran video animasi powtoon; (2) respons terhadap media } \\
\text { pembelajaran video animasi powtoon; (3) hasil belajar setelah menerapkan } \\
\text { media pembelajaran video animasi powtoon. Teknik pengumpulan data } \\
\text { dengan cara menggabungkan beberapa penelitian terdahulu untuk } \\
\text { menjawab kelayakan media, respons, dan hasil belajar setelah menerapkan } \\
\text { media pembelajaran video animasi powtoon. Penelitian terdahulu yang } \\
\text { sudah didapat selanjutnya dikumpulkan, dianalisis, dan disimpulkan } \\
\text { sehingga mendapatkan kesimpulan mengenai pengembangan media } \\
\text { pembelajaran dengan video animasi powtoon. Hasil penelitian (1) media } \\
\text { pembelajaran video animasi powtoon dinyatakan layak karena memenuhi } \\
\text { aspek-aspek kevalidan media terhadap video animasi powtoon diperoleh } \\
\text { persentase rata-rata penialain validasi } \geq 61 \% \text { - } 100 \% \text { dengan kualitatif baik } \\
\text { sampai sangat baik, (2) respons terhadap media pembelajaran video } \\
\text { animasi powtoon dikatakan baik karena responden menunjukkan } \\
\text { ketertarikan terhadap media dengan persentase rata-rata peniaian hasil } \\
\text { respons } \geq 61 \% \text { - } 100 \% \text { dengan kualitatif baik sampai sangat baik, (3) media } \\
\text { pembelajaran video animasi powtoon yang dapat meningkatkan hasil } \\
\text { belajar adalah media pembelajaran video animasi powtoon yang telah } \\
\text { memenuhi aspek kelayakan media serta hasil uji penerapan media } \\
\text { menunjukkan peningkatan hasil belajar setelah menerapkan video animasi } \\
\text { powtoon. }\end{array}$} \\
\hline $\begin{array}{l}\text { Riwayat Artikel: } \\
\text { Diterima: 04 Agustus } 2021 \\
\text { Revisi Akhir: 24 September } 2021 \\
\text { Disetujui: } 27 \text { September } 2021 \\
\text { Terbit: } 31 \text { Desember } 2021\end{array}$ & \\
\hline $\begin{array}{l}\text { Kata Kunci: } \\
\text { Animasi Powtoon } \\
\text { Media Pembelajaran } \\
\text { Pengembangan }\end{array}$ & \\
\hline & \\
\hline
\end{tabular}

\section{PENDAHULUAN}

Pendidikan merupakan unsur yang sangat berpengaruh dan sebagai faktor penentu terhadap mutu dari sumber daya manusia dalam suatu negara. Pendidikan ialah bentuk usaha dalam mencerdaskan kehidupan bangsa yang sudah tercantum dalam UUD 1945 (Rosmayanti \& Zanthy, 2019). Menurut Salafudin et al. (2018) pada dasarnya pendidikan merupakan usaha sadar untuk mengembangkan kepribadian dan kemampuan baik di dalam maupun di luar sekolah yang berlangsung seumur hidup. Sebagaimana menurut Hendriawan \& Septian (2019) yang menyatakan bahwa pendidikan adalah kebutuhan manusia sepanjang hayat. Hal ini membuat pendidikan sangat penting, karena tanpa pendidikan manusia akan sulit berkembang.

Perkembangan IPTEK di era globalisasi sangat pesat, semua bentuk inovasi dilakukan demi mewujudkan kesejahteraan masyarakat. Dalam bidang pendidikan, teknologi digunakan untuk mencapai tujuan pendidikan yang sesuai dengan tuntutan zaman \{Formatting Citation\}. Sedangkan menurut Pujiriyanto (2012) perkembangan teknologi sangat berpengaruh pada proses pembelajaran terutama dalam sistem penyampaian melalui pemanfaatan media generasi baru. Pemanfaatan teknologi dalam pembuatan media pembelajaran dapat dijadikan 
salah satu sarana yang bermanfaat terhadap perkembangannya serta menunjang mutu pendidikan. Menurut Hidayatulloh (2017) media pembelajaran berbasis teknologi dapat dijadikan pertimbangkan sebagai alternatif pembelajaran mandiri yang dapat dimanfaatkan dalam proses pembelajaran baik di kelas maupun di rumah. Salah satunya yaitu media pembelajaran berbasis komputer atau yang disebut multimedia pembelajaran. Sistem pembelajaran berbasis multimedia (teknologi yang menyertakan suara, gambar, dan video) dapat menyajikan materi pelajaran yang lebih menarik, tidak monoton, dan mempermudah penyampaian materi (Rohinah, 2015). Semakin banyak menggunakan panca indera ketika belajar, maka peserta didik akan lebih mudah dalam memahami materi (Hidayati et al., 2019).

Media dapat didefenisikan sebagai alat untuk menyampaikan pesan yang dapat merangsang pikiran dan perasaan peserta didik sehingga memunculkan motivasi untuk belajar (Arda et al., 2015; S. Safaruddin et al., 2020). Media pembelajaran berperan penting dalam pencapaian keberhasilan belajar peserta didik (One, 2017; Juhaeni et al., 2020). Media pembelajaran akan lebih memudahkan dan memperjelas materi pembelajaran (Musfiqon, 2019; Sri Bulan, \& W Eka Wahyudi. (2021). Media yang digunakan dalam pembelajaran beranekaragam dimulai dari media cetak hingga media audiovisual. Media audiovisual merupakan jenis media yang tidak hanya melibatkan suara tetapi juga gambar. Salah satu bentuk media audiovisual adalah media video animasi powtoon (Nurrita, 2018).

Liesdiani et al., (2016) menyatakan media pembelajaran berbasis audiovisual powtoon merupakan salah satu media pembelajaran berupa video yang menarik dan sebagai media pembelajaran pelengkap dengan ilustrasi dan bahasa yang digunakan juga lebih komunikatif dan bersahabat. Melalui media ini diharapkan mempermudah peserta didik dalam menguasai materi pelajaran. Peserta didik dapat mempelajari materi dari video tersebut tanpa dibatasi ruang dan waktu serta dapat mengunduh audiovisual powtoon melalui fitur yang tersedia di youtube yang dapat diakses di internet baik melalui laptop, tablet maupun smartphone. Dengan demikian akan memudahkan pendidik dalam menuntun pemahaman peserta didik dari nyata, ke semi nyata, lalu ke semi konseptual, dan yang terakhir dalam bentuk konseptual.

Berdasarkan paparan di atas, penelitian ini bertujuan mendeskripsikan kajian tentang: (1) bagaimana kelayakan media pembelajaran video animasi powtoon (2) bagaimana respons terhadap media pembelajaran video animasi powtoon (3) bagaimana hasil belajar setelah menerapkan media pembelajaran video animasi powtoon.

\section{METODE PENELITIAN}

\section{Latar Belakang Umum}

Pendekatan yang digunakan berupa studi literatur. Menurut Mardalis dalam Hartanto \& Dani (2020) menyatakan bahwa studi literatur dapat dilakukan dengan cara mencari rujukan dari beberapa penelitian terdahulu yang kemudian dikumpulkan untuk menarik kesimpulan. Hasil kumpulan rujukan dari beberapa penelitian terdahulu digunakan untuk menyimpulkan: (1) Bagaimana kelayakan media pembelajaran video animasi powtoon. (2) Bagaimana respons peserta didik terhadap media pembelajaran video animasi powtoon. (3) Bagaimana hasil belajar setelah menerapkan media pembelajaran video animasi powtoon. 


\section{Sampel}

Total artikel yang didapat sebanyak 30 artikel, beberapa buku, prosiding, serta skripsi yang sesuai dan mendukung studi literatur dalam penelitian ini. Penelitian ini menggunakan sampel sebanyak 20 artikel dari penelitian terdahulu, 3 buku, 2 prosiding, dan 2 skripsi online.

\section{Instrumen dan Prosedur}

Dalam penelitian ini peneliti bertindak sebagai instrumen karena peneliti mengambil dan mengumpulkan informasi berupa data-data dengan bantuan berbagai macam bahan yang ada seperti hasil penelitian terdahulu, buku, skripsi online, dan berbagai sumber yang berkaitan dengan tujuan yang ingin dicapai.

Adapun prosedur penelitian yang dilaksanakan yaitu sebagai berikut (Kulthau dalam (Mirzaqon et al., 2018)):

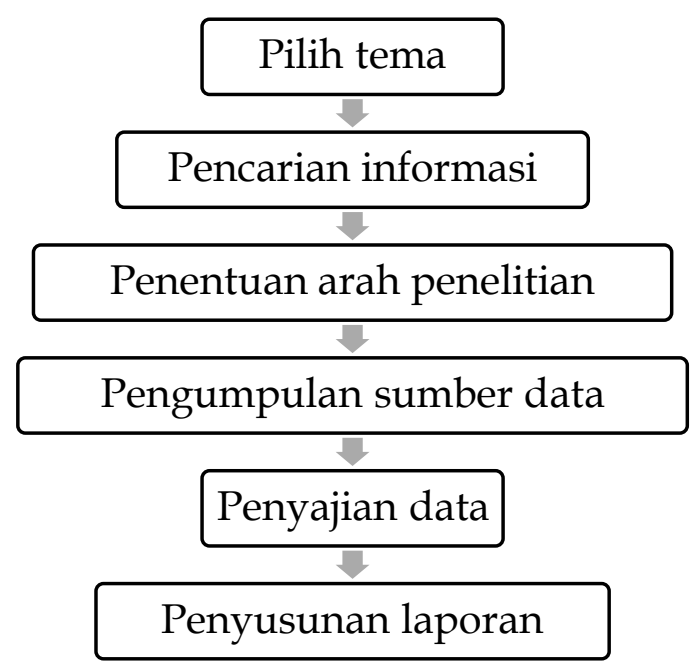

\section{Analisis Data}

Teknik analisis data menggunakan metode analisis isi yang dapat digunakan untuk memperoleh kesimpulan yang valid dan dapat diteliti kembali berdasarkan konteksnya. Analisis dilakukan dengan memilih, membandingkan, menggabungkan, dan menyeleksi beberapa pengertian dan penjelasan sehingga didapatkan data yang relevan (Sari \& Asmendri, 2020). Menurut Arikunto dalam Sari \& Asmendri (2020) mengemukakan bahwa metode analisis isi mengharuskan peneliti bekerja secara objektif dan sistematis untuk mendeskripsikan isi sebagai bahan komunikasi dengan pendekatan kuantitatif. Agar ketelitian proses pengkajian, mencegah, dan mengatasi mis-informasi tetap terjaga, maka dilakukan pengecekan setiap pustaka dan memperhatikan komentar pembimbing.

\section{HASIL DAN DISKUSI}

Kajian mengenai kelayakan media pembelajaran video animasi powtoon berisi tentang bagaimana media pembelajaran video animasi powtoon tersebut dapat dinyatakan layak. Pengujian kelayakan media pembelajaran video animasi powtoon dilakukan dengan cara melakukan validasi media dengan ketentuan mendapat persentase rata-rata penilaian $\geq$ 61\%-100\% kualitatif layak hingga sangat layak (Riduwan, 2013). Di dalam penilaian hasil validasi tersebut harus memenuhi beberapa aspek yaitu kesesuaian visual dengan materi, efektifitas dan efisiensi pencapaian kompetensi, kejelasan visual, dan ketajaman gambar (Iswadi et al., 2015). Kajian sementara yang sudah dilakukan oleh beberapa peneliti terdahulu mengenai kelayakan media pembelajaran dengan video animasi 
powtoon antara lain: (1) Juliana \& Rini (2017) dalam penelitiannya menunjukkan bahwa hasil validasi media mendapatkan persentase sebesar $88,04 \%$ secara kualitatif sangat baik dan layak digunakan (2) Wulandari et al. (2020) dalam penelitiannya menyatakan bahwa hasil validasi media mendapatkan persentase sebesar $89,8 \%$ secara kualitatif sangat baik dan layak digunakan. (3) Laksono et al. (2020) dalam penelitiannya menyatakan bahwa media pembelajaran video interaktif powtoon mendapatkan persentase $97 \%$ secara kualitatif sangat baik dan layak digunakan. (4) (Syafitri et al. (2019) dalam penelitiannya menyatakan bahwa hasil validasi media mendapatkan persentase $85 \%$ secara kualitatif sangat baik dan layak digunakan. (5) Latifah \& Lazulva (2020) dalam penelitiannya tentang media pembelajaran berbasis media video animasi powtoon mendapatkan persentase sebesar 85,45\% secara kualitatif sangat baik dan layak digunakan. (6) Farizi et al., (2019) dalam penelitiannya menunjukkan bahwa hasil data persentase sebesar $82 \%$ secara kualitatif sangat baik dan layak digunakan.

Kajian mengenai respons terhadap media pembelajaran video animasi powtoon berisi tentang seberapa besar ketertarikan responden terhadap media pembelajaran video animasi powtoon. Semakin besar nilai hasil rata-rata persentase ketertarikan responden terhadap media menunjukkan indikator bahwa media berfungsi untuk menyampaikan segala bentuk pesan atau informasi secara maksimal. Respon terhadap media pembelajaran dengan video animasi powtoon dilakukan dengan cara melakukan penyebaran kuisioner kepada responden terhadap media pada aspek kejelasan gambar, warna, dan kelengkapan materi dengan ketentuan mendapat persentase rata-rata penilaian $\geq 61 \%-100 \%$ dengan kualitatif baik hingga sangat baik (Riduwan, 2013). Kajian sementara yang sudah dilakukan oleh beberapa peneliti terdahulu mengenai respons terhadap media pembelajaran dengan video animasi powtoon antara lain: (1) Juliana \& Rini (2017) dalam penelitiannya tentang media pembelajaran berbasis powtoon menyatakan bahwa hasil respons peserta didik mendapatkan skor rata-rata $82,14 \%$ dengan kategori sangat baik. (2) Wulandari et al. (2020) menyatakan bahwa hasil respons peserta didik dalam penelitiannya mendapatkan persentase 96,36\% secara kualitatif sangat baik. (3) Latifah \& Lazulva (2020) dalam penelitiannya menyatakan bahwa respons peserta didik sangat baik dengan persentase $90 \%$.

Kajian mengenai hasil belajar yang meningkat setelah menerapkan media pembelajaran video animasi powtoon berisi tentang media pembelajaran video animasi powtoon bagaimana yang bisa dikatakan meningkatkan hasil belajar. Sebagaimana yang telah disebutkan di awal bahwa media pembelajaran berfungsi untuk menyampaikan segala bentuk pesan atau informasi. Di dalam media pembelajaran video animasi powtoon harus sudah mewakili materi yang akan disampaikan dalam bentuk gambar 2 dimensi maupun dalam bentuk gambar 3 dimensi. Di dalam pembuatan media pembelajaran dengan video animasi powtoon aspek validitas dan kepraktisan juga harus dipertimbangkan, sehingga gambar yang disajikan sesuai dengan kebutuhan dan masuk dalam katergori informatif. Kajian sementara yang sudah dilakukan oleh beberapa peneliti terdahulu tentang hasil belajar yang meningkat setelah menerapkan media pembelajaran video animasi powtoon antara lain: (1) Suhendra et al. (2018) dalam penelitiannya tentang penerapan media video animasi powtoon menyatakan bahwa peserta didik mendapatkan hasil belajar yang baik yaitu pada kelompok eksperimen kelas (VII D) yang menerapkan media pembelajaran video animasi powtoon mendapatkan nilai rata-rata 81,25 dan 28 peserta didik tuntas. Hasil belajar peserta didik pada kelompok konvensional kelas (VII F) dengan mendapatkan nilai rata-rata 51,85 dimana 6 peserta didik dinyatakan tidak tuntas. (2) Astika et al. (2019) dalam 
penelitiannya menyatakan bahwa peserta didik mendapatkan hasil belajar yang baik yaitu pada kelompok eksperimen kelas (VIII E) yang menerapkan media pembelajaran video animasi powtoon memperoleh nilai rata-rata pretest 25,66 dan posttest 81,33. Sedangkan hasil belajar pada kelompok konvensional kelas (VIII F) peserta didik mendapatkan nilai rata-rata pretest 28,16 dan posttest 54,83. (3) Fajar et al. (2017) dalam penelitiannya menyatakan bahwa peserta didik mendapatkan hasil belajar yang baik yaitu pada kelompok eksperimen yang menerapkan media pembelajaran video animasi powtoon mendapatkan skor rata-rata pretest 14,55 dan posttest 26,00. Hasil belajar peserta didik pada kelompok kontrol memperoleh skor rata-rata pretest 12,60 dan posttest 21,95.

\section{KESIMPULAN}

Berdasarkan kumpulan dan analisis mengenai pengembangan media pembelajaran video animasi powtoon yang telah dipaparkan, maka dapat ditarik kesimpulan: (1) Berdasarkan data hasil validasi menunjukkan bahwa media pembelajaran video animasi powtoon dikatakan layak digunakan, direspons baik, dan hasil belajar peserta didik meningkat. (2) Hasil penelitian ini sebagai masukkan kepada pengajar dalam upaya meningkatkan hasil belajar peserta didik dengan menerapkan media pembelajaran. (3) Sampel yang digunakan masih kurang dalam meningkatkan hasil belajar peserta didik. (4) Penelitian selanjutnya, disarankan untuk mengambil lebih banyak sampel untuk mendukung keterbaharuan penelitian ini. Dalam pengembangan penelitian tidak hanya meningkatkan hasil belajar berupa kognitif namun juga afektif dan psikomotorik, karena dari studi literatur yang dilakukan, penelitan terdahulu hanya menilai hasil belajar berupa kognitif saja.

\section{UCAPAN TERIMA KASIH}

Kami mengucapkan banyak terima kasih kepada para peneliti terdahulu yang telah meluangkan waktu dan fikirannya untuk meneliti tentang media pembelajaran dengan video animasi powtoon dan mengembangkannya serta terima kasih kepada pembimbing yang telah membimbing dalam pembuatan artikel ini.

\section{DAFTAR PUSTAKA}

Arda, S., S., \& Darsikin. (2015). Pengembangan media pembelajaran interaktif berbasis komputer untuk siswa SMP Kelas VIII. Mitra Sains, 3(1), 69-77.

Astika, R. Y., Anggoro, B. S., \& Andriani, S. (2019). Pengembangan video media pembelajaran matematika dengan bantuan powtoon. Jurnal Pemikiran dan Penelitian Pendidikan Matematika, 2(2), 85-96.

Fajar, S., Riyana, C., \& Hanoum, N. (2017). Pengaruh penggunaan media powtoon terhadap hasil belajar siswa pada mata pelajaran ilmu pengetahuan sosial terpadu. EDUTECHNOLOGI, 3(2), 101-114.

Farizi, Z. A., Sulisworo, D., Hasan, M. H., \& Rusdin, M. E. (2019). Pengembangan media animasi untuk mendukung pembelajaran berbasis TPACK dengan powtoon pada materi torsi SMA kelas XI. JP2F: Jurnal Penelitian Pembelajaran Fisika, 10(2), 108-113.

Hartanto, R. S. \& Dani, H. (2020) Studi literatur: pengembangan media pembelajaran dengan softwere autocad. Jurnal Kajian Pendidikan Teknik Bangunan, 6(1), 1-6.

Hendriawan, M. A., \& Septian, A. (2019). Pengembangan JIMATH sebagai multimedia pembelajaran matematika berbasis android untuk siswa sekolah menengah atas. IndoMath: Indonesia Mathematics Education, 2(1), 45-52. 
Hidayati, A., Adi, E., \& Praherdhiono, H. (2019). Pengembangan media video pembelajaran untuk meningkatkan pemahaman materi gaya kelas IV di SDN Sukoiber 1 Jombang. JINOTEP: Jurnal Inovasi dan Teknologi Pembelajaran, 6(1), 45-50.

Hidayatulloh, M. (2017). Pengembangan meedia pembelajaran menggunakan software adobe flash pada pokok bahasan barisan dan deret kelas XII SMA Negeri 16 Makasar. [Skripsi]. Fakultas Tarbiyah dan Keguruan UIN Alauddin, Makassar.

Iswadi, M., Harlin, \& Santosa, M. A. (2015). Pengembangan media pembelajaran menggunakan autocad pada mata kuliah gambar teknik di program studi pendidikan teknik mesin universitas sriwijaya. Jurnal Pendidikan Teknik Mesin, 2(2): 82-96.

Juhaeni, Safaruddin, R Nurhayati, \& Aulia Nur Tanzila. (2020). Konsep Dasar Media Pembelajaran. JIEES : Journal of Islamic Education at Elementary School, 1(1), 34-43. https://doi.org/10.47400/jiees.v1i1.11

Juliana, E. \& Rini. (2017). Pengembangan media pembelajaran berbasis powtoon pada pokok bahasan struktur atom di kelas x sma/sederajat. Jurnal Online Mahasiswa Fakultas Keguruan dan Ilmu Pendidikan, 4(2), 1-10.

Laksono, D., Iriansyah, H., S., \& Oktaviana, E. (2020). Pengembangan media pembelajaran video interakrif powtoon pada mata pelajaran IPA materi komponen ekosistem. In 2nd SEMNARA 2020 seminar nasional pendidikan, STKIP.

Latifah, N., \& Lazulva, L. (2020). Desain dan uji coba media pembelajaran berbasis video animasi powtoon sebagai sumber belajar pada materi sistem periodik unsur. Journal Education and Chemistry, 2(1), 26-31.

Liesdiani, D., Syaodih, E., \& Mariam, P. (2016). Pengembangan multimedia pembelajaran berbasis audio visual powtoon untuk meningkatkan motivasi belajar. JP2EA: Jurnal Pendidikan dan Pembelajaran Ekonomi Akuntansi, 2(2), 139-149.

Mirzaqon, T., A., \& Purwoko, B. (2018). Studi kepustakaan mengenai landasan teori dan praktik konseling expressive writing. Jurnal BK Unesa, 8(1), 1-8.

Musfiqon. (2019). Pengembangan media belajar dan sumber belajar. Prestasi Pustakakarya.

Nurrita, T. (2018). Pengembangan media pembelajaran untuk meningkatkan hasil belajar siswa. Jurnal Misykat, 3(1), 171-187.

One. (2017). Efektivitas penggunaan media pembelajaran audiovisual powtoon dalam meningkatkan motivasi belajar siswa di madrasah aliyah. Jurnal Pendidikan dan Pembelajaran Khatulistiwa, 6(3).

Pujiriyanto. (2012). Teknologi untuk pengembangan media dan pembelajaran. UNY Press.

Riduwan. (2013). Dasar-dasar statistika (edisi revisi). Alfabeta.

Rohinah. (2015). Pengembangan aplikasi bahan ajar pendidikan agama islam berbasis android di sekolah menengah atas. Al-Athfal : Jurnal Pendidikan Anak, 1, 79-94.

Rosmayanti, D., \& Zanthy, L. S. (2019). Pengembangan media pembelajaran berbasis visual basic application powerpoint pada materi sistem persamaan linear dua variabel. Jurnal Pembelajaran Matematika Inovatif, 2(6), 401-414.

Salafudin, P., D., S. L., \& Rini, J. (2018). Pengembangan bahan ajar matematika SMP berwawasan nasionalisme dan kemandirian. MaPan: Jurnal Matematika Dan Pembelajaran, 6, 20-30.

Safaruddin, S., Degeng, I. N. S., Setyosari, P., \& Murtadho, N. (2020). The Effect of PjBL with WBL Media and Cognitive Style on Students' Understanding and Science-Integrated Concept Application. Jurnal Pendidikan IPA Indonesia, 9(3), 384-395. https://doi.org/10.15294/jpii.v9i3.24628

Safaruddin, Safaruddin, Ibrahim, N., Juhaeni, J., Harmilawati, H., \& Qadrianti, L. (2020). The Effect of Project-Based Learning Assisted by Electronic Media on Learning Motivation and 
Science Process Skills. Journal of Innovation in Educational and Cultural Research, 1(1), 22-29. https://doi.org/10.46843/jiecr.v1i1.5

Sari, M. \& Asmendri. (2020). Penelitian kepustakaan (Library Reasearch) dalam penelitian pendidikan IPA. Jurnal Penelitian Bidang IPA dan Pendidikan IPA, 6(1), 4153.

Suhendra, I., Enawaty, E., \& Melati, H. A. (2018). Pengaruh penggunaan media audiovisual powtoon terhadap motivasi dan hasil belajar siswa materi unsur senyawa campuran. Jurnal Pendidikan dan Pembelajaran Khatulistiwa, 7(3), 1-8.

Sri Bulan, \& W Eka Wahyudi. (2021). Pengembangan Media Pembelajaran Al-Qur'an Hadits

Terintegrasi Seni Melalui Narasi Berbasis Gambar Bercerita Surat Al-Fil Untuk

Membangun Kemampuan Berpikir Siswa. Journal of Instructional and Development

Researches, 1(1), 10-19. https://doi.org/10.53621/jider.v1i1.18

Syafitri, D., Nevrita., \& Asikin, N. (2019). Multimedia berbasis powtoon materi sistem pernapasan manusia kelas VIII: dikaji dari aspek validitas. Universitas Maritim Raja Ali Haji.

Wisudawan, W., Hendriana, B., Nuriadin, I., \& Ramza, H. (2017). Pengembangan aplikasi math mobile learning bangun datar berbasis android pada materi segitiga dan segiempat pelajaran matematika di tingkat SMP. Seminar Nasional TEKNOKA, 2, 813.

Wulandari, Y., Ruhiyat, Y., \& Nulhakim, L. (2020). Pengembangan media video berbasis powtoon pada mata pelajaran IPA di kelas V. Jurnal Pendidikan Sains Indonesia, 8(2), 269-279.

\footnotetext{
* Titin (Corresponding Author)

Universitas tanjungpura,

Jl. Prof. Dr. H. Hadari Nawawi, Pontianak, West Borneo, 78124, Indonesia

Email: titin@fkip.untan.ac.id
}

Ega Safitri

Universitas tanjungpura,

Jl. Prof. Dr. H. Hadari Nawawi, Pontianak, West Borneo, 78124, Indonesia

Email: egasafitri1399@gmail.com 